\title{
Edible, medicinal and red listed monkey head mushroom Hericium erinaceus (Bull.) Pers. from Japfu mountain of Kohima needs immediate protection
}

\author{
T. Wabang, T. Ajungla \\ Department of Botany, Nagaland University, Lumami, Nagaland, India
}

Received: 06.06.2016

Revised: 02.07.2016

Accepted: 08.07.2016

*Address for correspondence:

T. Wabang. Department of Botany, Nagaland University, Lumami - 798627

Nagaland, India.

Email: temjenlkr@gmail.com

\begin{abstract}
Hericium erinaceus, also called as monkey head mushroom or bearded tooth fungi, is an edible and medicinal mushroom. It is available in the Japfu mountain of Kohima district Nagaland (India) which has an altitude of about $3000 \mathrm{~m}$. This mushroom is considered very rare in many countries and was red listed in 13 out of 23 European countries, in which it has been recorded and is one of the flagship species for conservation of fungal biodiversity in India. This rare and valuable mushroom needs protection as it is considered to be one of the best edible mushrooms and reported to have contain many medicinal properties and above all the local population collect and destroy this mushroom from the wild out of curiosity because of its peculiar look.
\end{abstract}

KEY WORDS: Biodiversity, flagship, Japfu, red list

\section{INTRODUCTION}

Mushroom hunting for food is an age-old practice for the tribal population of North Eastern Indian states as mushrooms are considered highly nutritious. Lately, our attention is drawn onto the second area of exploitation of this delicate organism because many of the mushrooms are reported to produce metabolites which are nutriceutical and pharmaceutical agents.

Hericium erinaceus, also called as Lion's Mane mushroom or bearded tooth fungus, is an edible and medicinal mushroom belonging to tooth fungus. It is considered to be one of the best edible mushrooms and reported to have contain many nutriceutical and pharmaceutical agents. It contain neuroactive compounds (Kah-Hui et al., 2007), it has antioxidant and anti-inflammatory effect (Phan et al., 2015), and improve cognitive impairment (Mori et al., 2009) also the polysaccharides from this mushroom possess anti-tumor property (Lee and Hong et al., 2010).

$H$. erinaceus is sighted rarely in and around the forests of Japfu mountain in Kohima district usually during the months of October-November. Apart from its culinary, medicinal and nutriceutical values, this mushroom is being collected by the local population out of curiosity due to its peculiarly beautiful appearance. This mushroom will become more vulnerable to extinction when its reported pharmaceutical and nutriceutical importance are known to the local population without proper management guidelines, and thus, require urgent conservation attention.

\section{MATERIALS AND METHODS}

\section{Study Site}

Nagaland is one of the North Eastern Indian states with a total geographical area of $16,579 \mathrm{~km}^{2}$. Nagaland is bordered by Myanmar in the East, Assam in the West, Arunachal Pradesh and a part of Assam in the North, and Manipur in the South. It is situated between $93^{\circ} 20^{\prime}$ and $95^{\circ} 15^{\prime}$ East longitude and $25^{\circ} 6^{\prime}$ and $26^{\circ} 4^{\prime}$ North latitude. The recorded annual rainfall ranges from $2000 \mathrm{~mm}$ to $2500 \mathrm{~mm}$. The temperature during the summer season remains between $16^{\circ} \mathrm{C}$ and $31^{\circ} \mathrm{C}$ and drops below $4^{\circ} \mathrm{C}$ during winter and frost is common in high elevation such as in rocky Japfu peak. 
Kohima, the capital of Nagaland, is situated at an elevation of $1444 \mathrm{~m}$ above the sea level with an average temperature between $14.6^{\circ} \mathrm{C}$ and $22.2^{\circ} \mathrm{C}$. The annual rainfall is around $1831.3 \mathrm{~mm}$. The forest in and around Japfu mountain represents a typical Eastern Himalayan vegetation.

\section{Sample Collection}

This mushroom was collected from the forest of Japfu mountain during the month of November 2014. The collection was done based on the presence of sporophores of the species (Vogt et al., 1992). The habitat and the morphological characteristics of the mushroom were noted (Lodge et al., 2004), and color photographs were taken. The collected sporocarps were described for their morphological characters such as color, size, shape, odor, and texture and identified based on the standard microscopic method (Roy and De, 1996).

\section{RESULTS}

The fruit body of bearded tooth fungi is a large irregularly bulbous compact white to creamy mass of up to $40 \mathrm{~cm}$ in diameter and weighing up to $1 \mathrm{~kg}$ when it is fresh. It consists of numerous long slender spines hanging from a tough solid plug of tissue. The tissue is white when fresh and becomes brownish when aged. The spines measure up to $5 \mathrm{~cm}$ long and soft. The spores measures $4 \mu \mathrm{m} \times 6 \mu \mathrm{m}$, subglobose, nearly round and smooth. It is found mostly growing solidary from wounds on living hardwood or felled log during the fall-winter (Figure 1).

\section{DISCUSSION}

Fungi are a mega-diverse group of organism currently estimated to be about 1.5 million species (Hawksworth, $1991 ; 2001)$. Of these, only $8-10 \%$ have been discovered and described. At the current rate of description, a total
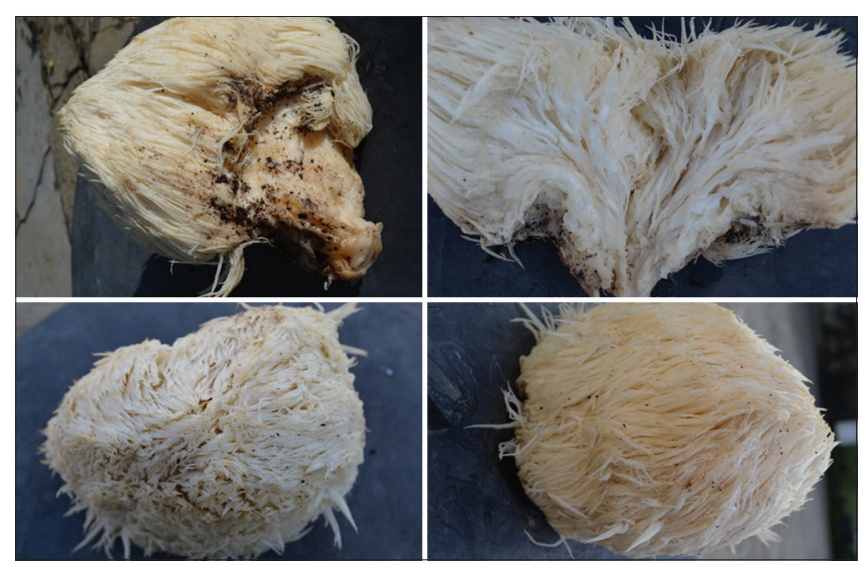

Figure 1: Hericium erinaceus $(16 \mathrm{~cm} \times 12 \mathrm{~cm})$ inventory will take 1290 years (Hawksworth, 2003). Unfortunately, many habitats are under threat from destruction, modification, and fragmentation and it is likely that a substantial number of both micro and macro fungi will be extinct long before they are described. In the late 1980 s, it was estimated that $25 \%$ of biodiversity present would be gone within 25 years, i.e., by the early $21^{\text {st }}$ century (Raven, 1988; Hawksworth, 1991) which would include the loss of 376,000 fungal species more than 5 times the number presently described (Hawksworth, 1991). In India about 1105-1208 species of mushrooms belonging to 128-130 genera have been documented in comparison to 14,000 species worldwide. Among these, 300-315 species belonging to 75-80 genera are considered edible.

Despite being an extremely diverse and relatively understudied group, fungal conservation lag behind the protection of plants and animals due to a combination of lack of knowledge of so many species, their often relatively uncharismatic appearance and the difficulties of assessing them using established criteria (Heilmann-Clausen and Vesterholt, 2008).

H. erinaceus is one of the flagship species for conservation of fungal biodiversity in India. It is also considered very rare in many European countries and in the year 2003 and it was red listed in 13 out of 23 countries in which it had been recorded. In India and in particular the North Eastern states, many wild fungi are collected for food and medicine which also provide a much needed alternative income for many rural households. However, recent reports suggest that the quantity of these edible mushrooms is rapidly declining all over the country which is attributed to climate change, overexploitation and habitat destruction, etc.

\section{CONCLUSION}

The introduction of management guidelines allowing for a more sustained approach to the use of wild mushroom is required immediately and by creating awareness of these issues among the local people, we will enable a more sustainable use of this natural product.

\section{ACKNOWLEDGMENT}

The authors are grateful to the Government of Nagaland for providing necessary financial support for the study and to Botany Department Nagaland University providing adequate laboratory facilities. 


\section{REFERENCES}

Hawksworth DL. The fungal dimension of biodiversity its magnitude and significance. Mycol Res 1991;95:441-56.

Hawksworth DL. Monitoring and safeguarding fungal resources worldwide: The need for an international collaborative Myco action plan. Fungal Divers 2003;13:29-45.

Hawksworth DL. The magnitude of fungal diversity. Mycol Res 2001;105:1422-32.

Heilmann-Clausen J, Vesterholt J. Conservation, selection criteria and approaches. Ecology of Saprotropic Basidiomycetes. Amsterdam: Elsevier; 2008. p. 325-47.

Kah-Hui W, Sabaratam V, Murali N, Roger K. Activity of aqueous extract of lion's mane mushroom Hericium erinaceus (Bull. Fr.) Pers. (Aphyllophoromycetideae) on the neural cell line NG 108-15. Int J Med Mushrooms 2007;9:57-65.

Khan MA, Tania M, Liu R, Rahman MM. Hericium erinaceus: An edible mushroom with medicinal value. J Complement Integr Med 2013;10:253-8.

Lee JS, Hong EK. Hericium erinaceus enhances doxorubicininduced apoptosis in human hepatocellular carcinoma cells. Cancer Lett 2010;297:144-54.
Lodge DJ, Ammirati JF, Thomas EO, Gregory MM. Collecting and describing macrofungi. Amsterdam: Elsevier Academic Press; 2004.

Mori K, Inatomi S, Ouchi K, Azumi Y, Tuchida T. Improving effects of the mushroom Yamabushitake (Hericium erinaceus) on mild cognitive impairment: A double-blind placebocontrolled clinical trial. Phytother Res 2009;23:367-72.

Phan CW, David P, Naidu M, Wong KH, Sabaratnam V. Therapeutic potential of culinary-medicinal mushroom for the management of neurodegenerative diseases: Diversity, metabolites and mechanism. Crit Rev Biotechnol 2015;35:355-68.

Raven PH. Tropical floristics tommorow. Taxon 1988;37:54960.

Roy A, De A. Polyporaceae of India. Dehradun: International Book Distributor; 1996.

Vogt KA, Bloomfield J, Ammirati JF, Ammirati SR. Sporocarp production by Basidiomycetes with emphasis on forest ecosystem. In: Carroll GC, Wicklow DT, editors. The Fungal Community: Its Organization and Role in the Ecosystem. 2 ${ }^{\text {nd }}$ ed. New York: Marel Dekker; 1992. p. 563-81. 